Pathophysiology of Haemostasis and Thrombosis
Pathophysiol Haemost Thromb 2007-08;36:227-232

DOI: $\underline{10.1159 / 000252817}$
Received: June 25, 2009

Accepted after revision: August 17, 2009

\title{
Nattokinase-Promoted Tissue Plasminogen Activator Release from Human Cells
}

\author{
Chieko Yatagai $^{a}$ b Masugi Maruyama ${ }^{b}$ Tomoko Kawahara $^{a}$ Hiroyuki Sumi ${ }^{a}$ \\ a Department of Physiological Science, Kurashiki University of Science and the Arts, Kurashiki, and \\ ${ }^{b}$ Department of Physiology, Faculty of Medicine, University of Miyazaki, Miyazaki, Japan
}

\section{Key Words}

Nattokinase $\cdot$ Bacillus subtilis natto $\cdot$ Tissue plasminogen activator $\cdot$ Human vascular endothelial cell

\begin{abstract}
When heated to a temperature of $70^{\circ} \mathrm{C}$ or higher, the strong fibrinolytic activity of nattokinase in a solution was deactivated. Similar results were observed in the case of using SucAla-Ala-Pro-Phe-pNA and H-D-Val-Leu-Lys-pNA, which are synthetic substrates of nattokinase. In the current study, tests were conducted on the indirect fibrinolytic effects of the substances containing nattokinase that had been deactivated through heating at $121^{\circ} \mathrm{C}$ for $15 \mathrm{~min}$. Bacillus subtilis natto culture solutions made from three types of bacteria strain were heat-treated and deactivated, and it was found that these culture solutions had the ability to generate tissue plasminogen activators (tPA) from vascular endothelial cells and HeLa cells at certain concentration levels. For example, it was found that the addition of heat-treated culture solution of the Naruse strain (undiluted solution) raises the IPA activity of HeLa cells to about 20 times that of the control. Under the same conditions, tPA activity was raised to a level about 5 times higher for human vascular endothelial cells (HUVEC), and to a level about 24 times higher for nattokinase sold on the market. No change in cell count was observed for HeLa cells and HUVEC in the culture solution at these concentrations, and the level of activity was found to vary with concentration.

Copyright $\odot 2009$ S. Karger AG, Basel
\end{abstract}

\section{Introduction}

In the autumn of 1982, Sumi et al. [1] discovered that nattō, a traditional fermented food in Japan, possesses a hitherto unidentified and very strong fibrinolytic activity. Because the isolated fibrinolytic enzyme had a very strong fibrinolytic activity similar to that of plasmins, the enzyme was named 'nattokinase'.

Nattokinase was extracted from nattō sold on the market, purified and packed in enteric-coated capsules, and the 1.3-gram capsules were orally administered to test subjects three times a day. Plasma euglobulin fractions were obtained over a period of time by drawing blood from the test subjects. It was found that with the gradual rise in euglobulin fibrinolytic activity of the plasma euglobulin fractions, there was a significant increase $(p<0.001)$ in fibrin degradation products in the blood, starting from the first day on which nattokinase was orally administered. An increase in tissue plasminogen activator (tPA) was also observed [2]. It should be noted that since bacteria (Bacillus subtilis natto) are the source of nattokinase, the mass production of nattokinase is possible at a very low cost. It was also found that nattokinase is relatively stable in relation to heat and acidity, and that its separation and purification is quite easy. One of the most noteworthy characteristics of nattokinase is the fact that nattō itself has been consumed in daily life by common Japanese people for more than 1,000 years, which provides strong reassurance on the safety of the oral ad-

\section{KARGER}

Fax +41613061234

E-Mail karger@karger.ch

www.karger.com
(C) 2009 S. Karger AG, Basel

$1424-8832 / 08 / 0365-0227 \$ 24.50 / 0$

Accessible online at:

www.karger.com/pht
Hiroyuki Sumi

Department of Physiological Science, Kurashiki University of Science and the Arts 2640 Tsurajima-cho-Nishinoura

Kurashiki, Okayama, 712-8505 (Japan)

Tel./Fax +81 86440 1074, E-Mail sumi@chem.kusa.ac.jp 
ministration of nattokinase [3-5]. The three strains by Naruse, Miyagino and Takahashi have been used as seed bacteria for a long time in fermentation processes for food preservation in Japan, which means the safety of these strains is also assured [4].

In the current study, the effects of nattokinase on human vascular endothelial cells (HUVEC) and HeLa cells were observed after the nattokinase was heat-treated and deactivated. As a result, it was found that the activity of nattokinase is not limited to that of conventional active types, and that heat-treated and deactivated nattokinase also shows strong activity in releasing tPA from living cells.

\section{Materials and Methods}

For B. subtilis natto, the following three representative strains of seed bacteria used for food in Japan were used: the Naruse strain (Naruse Fermentation Chemical Laboratory KK, Tokyo, Japan), the Miyagino strain (Miyagino Natto Seizoujo, Sendai, Japan) and the Takahashi strain (Yuzo Takahashi Laboratory, Yamagata, Japan). The IFO 3301 strain of Escherichia coli was purchased from the Institute for Fermentation, Osaka, Japan (IFO). The nattokinase that currently has the highest level of purity was supplied by Honda Trading Corporation (Tokyo, Japan; about $20,000 \mathrm{FU} / \mathrm{g}$ ). Bovine fibrinogens and fetal bovine serum (FBS) were purchased from Sigma-Aldrich, and bovine thrombins from Mochida Pharmaceutical Co., Ltd. (Tokyo, Japan).

\section{Bacillus subtilis natto Propagation Product}

For the heat-treated product of the B. subtilis natto culture solution, $3 \%$ dry bouillons were used as medium. $250 \mathrm{ml}$ of the medium was placed in a 500-ml Erlenmeyer/shaker flask, and after performing heat sterilization at $121^{\circ} \mathrm{C}$ for $15 \mathrm{~min}$ in an autoclave, 1 platinum loop of the slant-cultured bacteria $\left(5 \times 10^{5} / \mathrm{ml}\right)$ was inoculated. Then the culture was shaken at $100 \mathrm{rpm}$ for $96 \mathrm{~h}$ at $37^{\circ} \mathrm{C}$. After the preparation of the culture was complete, the supernatant was heat-treated in an autoclave and filtered through a $0.2-\mu \mathrm{m}$ membrane filter (Advantec KGS-47-TF), with the resulting product used as the test sample.

\section{Cell Culture}

FBS, Eagle's amino acids and vitamins medium, L-glutamine and sodium bicarbonate were added to Eagle's MEM. In this culture solution, at $37^{\circ} \mathrm{C}$ under partial pressure of $5 \% \mathrm{CO}_{2}, \mathrm{HeLa} \mathrm{S} 3$ cells (Dainippon Sumitomo Pharma Co., Ltd., Osaka, Japan) were multiplied and subcultured in $25-$ or $75-\mathrm{cm}^{2}$ culture flasks (Falcon). The multiplied HeLa S3 cells were separated by using $0.25 \%$ trypsin and suspended in fresh culture solution. A measurement of the cell count was conducted using a hemacytometer. These cells were put in a 24 -well plate (Falcon) at a rate of $1 \times 10^{5}$ cells/ $\mathrm{cm}^{2}$. After the culture was performed and reached the confluent state, the used culture solution was disposed of. After washing the cells twice with $500 \mu \mathrm{l}$ of FBS, $450 \mu \mathrm{l}$ of fresh culture solution and $50 \mu \mathrm{l}$ of reagents were added. The culture solution collected after a culture of $24 \mathrm{~h}$ was established as the '1st medium'. Centrifugal separation was performed on the collected culture solution at $4^{\circ} \mathrm{C}$ and 4,000 rpm for $10 \mathrm{~min}$. The supernatant was collected and stored at $-20^{\circ} \mathrm{C}$ until it was used for each test [6].

The multiplication medium for human endothelial cells was used for HUVEC (Toyobo Co., Ltd., Osaka, Japan) [7]. In a process similar to that for the HeLa cells, the cells were placed in a 24-well plate and cultured at $37^{\circ} \mathrm{C}$ under partial pressure of 5\% $\mathrm{CO}_{2}$ until reaching the confluent state. After disposing of the used culture solution and washing the cells with FBS, $450 \mu \mathrm{l}$ of fresh culture solution and $50 \mu \mathrm{l}$ of reagents were added and the culture solution collected, after a culture of $24 \mathrm{~h}$ was established as the '1st medium'. For the collected culture solution, centrifugal separation was performed at $4^{\circ} \mathrm{C}$ and $4,000 \mathrm{rpm}$ for $10 \mathrm{~min}$. The supernatant was recovered and stored at $-20^{\circ} \mathrm{C}$ until used for each test.

\section{Cell Count}

After the culture solution was collected, the cells remaining on the plate were separated using $0.25 \%$ trypsin-EDTA and suspended in culture solution and PBS for a measurement of the cell count based on an absorbance at $600 \mathrm{~nm}$. The cell count was calculated based on a calibration curve $\left(\mathrm{A}_{600} 1.0=13.4 \times 10^{5}\right.$ cells $/ \mathrm{ml})$.

\section{Fibrinolytic Activity}

Nattokinase activity was shown by the lysis area $\left(\right.$ in $\mathrm{mm}^{2}$ ) in artificial thrombi through the standard fibrin plate method [8]. An amount of $30 \mu \mathrm{l}$ of the culture solution collected from the well plate was placed on each $0.5 \%$ fibrin plate, which was created by using fibrinogens, borate-buffered saline ( $\mathrm{pH}$ 7.8) and thrombins. After incubation at $37^{\circ} \mathrm{C}$, the lysis area was measured after $4 \mathrm{~h}$ for nattokinase and after $48 \mathrm{~h}$ for other substances.

\section{Amidase Activity}

Nattokinase activity was also determined by the colorimetric method by using the synthetic substrate Suc-Ala-Ala-Pro-PhepNA or H-D-Val-Leu-Lys-pNA. The reaction mixture $(1 \mathrm{ml})$ contained $100 \mu \mathrm{l}$ of the substrate (final concentration of $5 \times 10^{-4} \mathrm{M}$ ) and $0.1 \mathrm{M}$ borate-buffered saline at $\mathrm{pH}$ 7.8. The amount of pNA released was determined based on the absorbance at $405 \mathrm{~nm}$.

\section{Zymography}

To conduct zymography on the culture solutions, SDS-PAGE was performed on $10 \%$ gel slabs, after which the gel was washed with Triton X-100 for $30 \mathrm{~min}$. Then the gel was layered on top of the fibrin plate containing agar that was created inside a square petri dish, and after incubation at $37^{\circ} \mathrm{C}$, the bands that were formed were identified [9]. As the molecular weight standard, tPA (68 kDa; hapase, 3,600,000 U/vial; Kowa Pharmaceutical Co., Ltd.) was used.

\section{Reverse Transcriptase Polymerase Chain Reaction}

HeLa cells were cultured in $25-\mathrm{cm}^{2}$ culture flasks until reaching the confluent state. After treatment with the heated product of B. subtilis natto culture solution for $24 \mathrm{~h}$, the conditioned medium was replaced with a fresh one. The conditioned medium was collected after incubation for $24 \mathrm{~h}$. The cells were washed twice with PBS, and total RNA was extracted by the acid guanidinium thiocyanate-phenol-chloroform method [10]. The cDNA templates were synthesized using SuperScript II. To prepare the PCR 


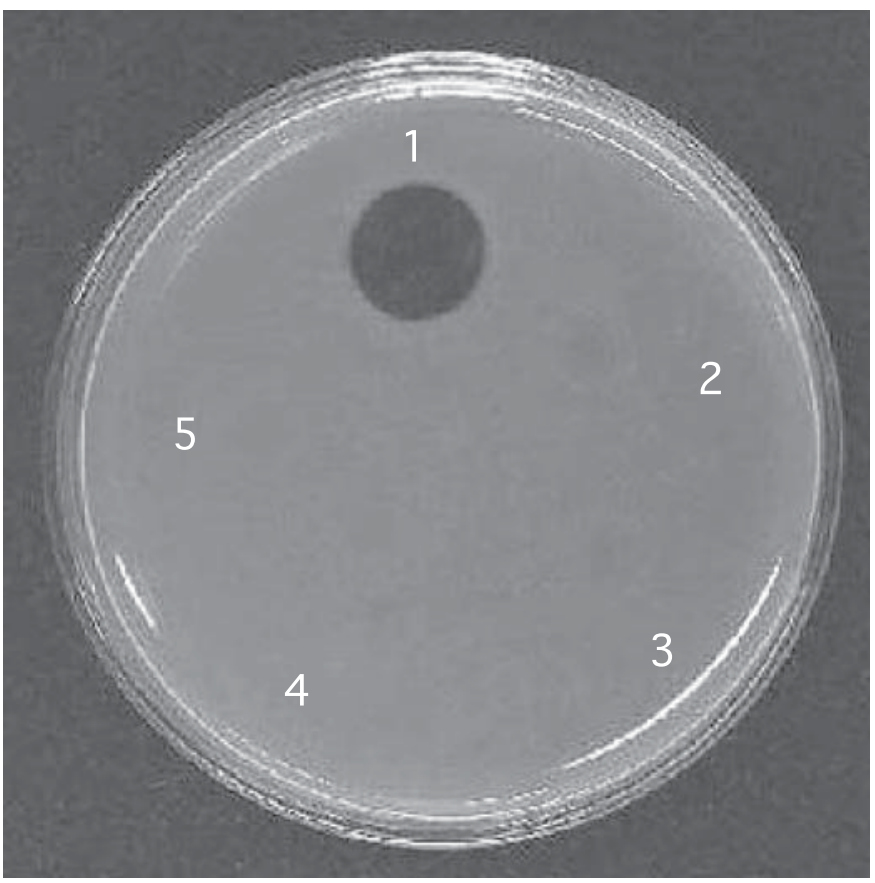

Fig. 1. Deactivation by heat treatment as observed for fibrinolytic activity. The lysis area $\left(\mathrm{mm}^{2}\right)$ on the fibrin plate was measured for $30 \mu \mathrm{l}$ of the sample after $4 \mathrm{~h}$ at $37^{\circ} \mathrm{C}$. Results for $20 \mathrm{FU} / \mathrm{ml}(1 \mathrm{mg})$ nattokinase before and after heat treatment, for the control $\left(20^{\circ} \mathrm{C}\right)$ and at $70,80,90$ and $100^{\circ} \mathrm{C}(10 \mathrm{~min}) .1=$ Control; $2=70^{\circ} \mathrm{C} ; 3=$ $80^{\circ} \mathrm{C} ; 4=90^{\circ} \mathrm{C} ; 5=100^{\circ} \mathrm{C}$.

to amplify the tPA gene, the following primers were used as forward and reverse primers, respectively: $5^{\prime}$-ATC TTG GGC AGA ACA TAC CG-3' and 5'-TGC ACT CTT CCC TCT CCT GT3'. Using glyceraldehyde 3-phosphate dehydrogenase (GAPDH) cDNA as the internal standard, we performed RT-PCR with $5^{\prime}$ GAG TCA ACG GAT TTG GTC G-3' and 5'-TCG CTG TTG AAG TCA GAG GA-3' as the forward and reverse primers, respectively [11].

\section{Statistical Analysis}

The differences between mean values were analyzed by the Student $t$ test [12].

\section{Results}

Nattokinase was diluted to $20 \mathrm{FU} / \mathrm{ml}\left(1 \mathrm{mg} ; 30^{\circ} \mathrm{C}\right)$ with saline and was heat-treated for $10 \mathrm{~min}$ at temperatures between 70 and $100^{\circ} \mathrm{C}$, which resulted in deactivation at $70^{\circ} \mathrm{C}$ for each of the samples (fig. 1). The results were similar with heating solutions of $B$. subtilis natto culture made from the three strains of bacteria. Similarly, the strong amidase activity of nattokinase for Suc-

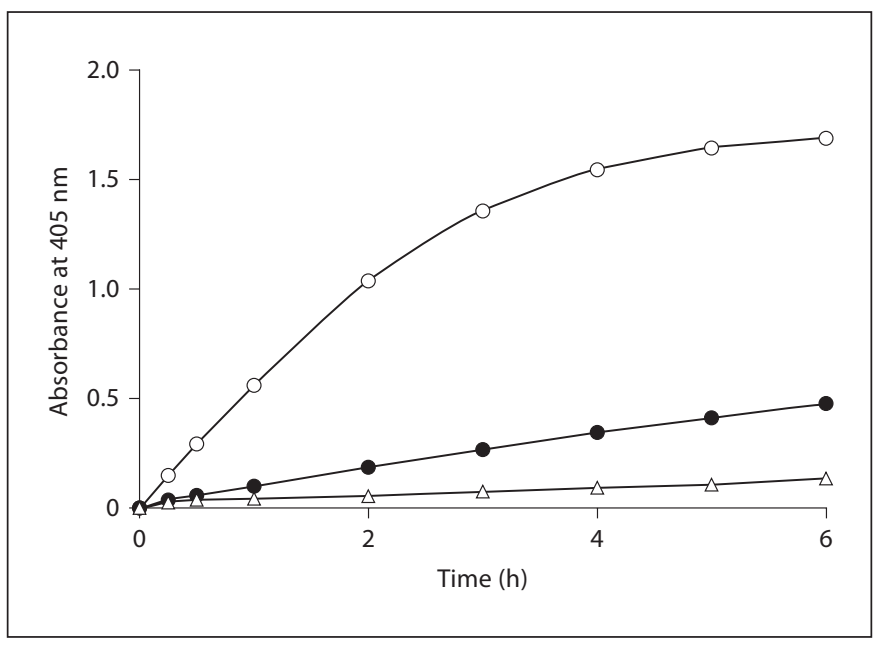

Fig. 2. Activity of $20 \mathrm{FU} / \mathrm{ml}$ nattokinase for Suc-Ala-Ala-Pro-PhepNA. $\bigcirc=100 \mu \mathrm{l} / \mathrm{ml} ; \bullet=10 \mu \mathrm{l} / \mathrm{ml} ; \triangle=1 \mu \mathrm{l} / \mathrm{ml}$.

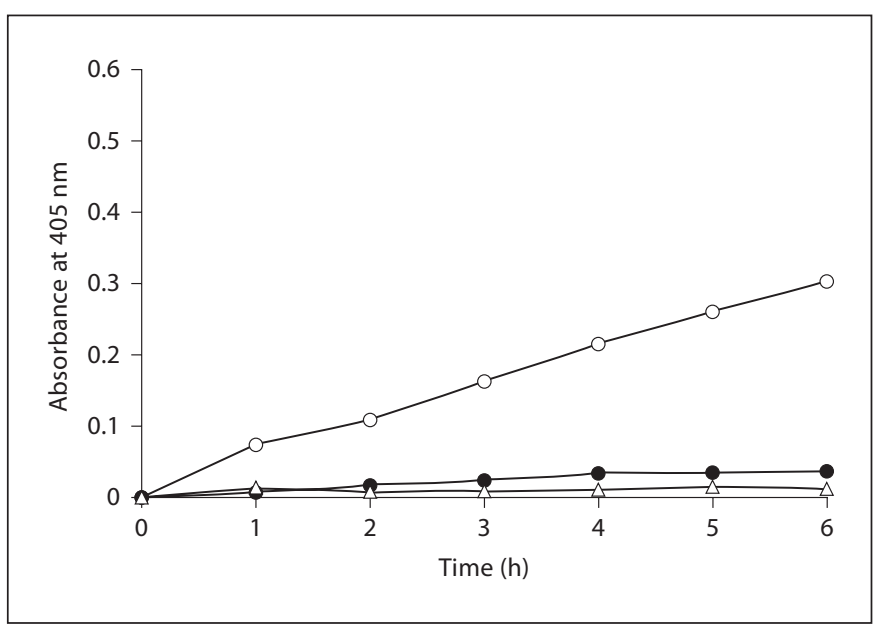

Fig. 3. Activity of $20 \mathrm{FU} / \mathrm{ml}$ nattokinase for H-D-Val-Leu-LyspNA. $\bigcirc=1 \mathrm{mg} / \mathrm{ml} ; \bullet=100 \mu \mathrm{l} / \mathrm{ml} ; \triangle=10 \mu \mathrm{l} / \mathrm{ml}$.

Ala-Ala-Pro-Phe-pNA, H-D-Val-Leu-Lys-pNA and other substrates [9] was deactivated when heat-treated for $10 \mathrm{~min}$ at $100^{\circ} \mathrm{C}$ (fig. 2, 3; cases with no activity observed have been omitted).

Zymography was applied to the heat-treated product of $B$. subtilis natto culture solution made from the Naruse strain, a representative $B$. subtilis natto strain, and a check was conducted on the molecular species of enzymes affecting HeLa cells (fig. 4). Although no activity was observed for any of the enzyme solutions, it was found that the addition of $1 / 8-1$ (undiluted solution) of the heat- 


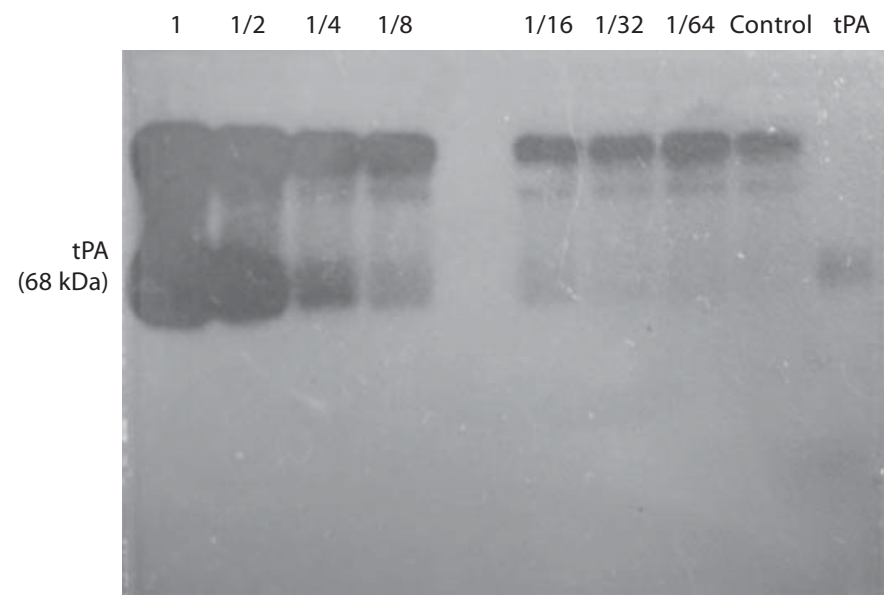

Fig. 4. Zymography (active enzymes after SDS-PAGE) of HeLa medium. 1-1/64: Dilution of heated original culture (Naruse strain). tPA: shown for standard tPA.
Table 1. tPA-generating effects of heat-treated products of $B$. subtilis natto culture solutions containing the major strains of seed bacteria

\begin{tabular}{llllll}
\hline $\begin{array}{l}\text { Sample } \\
\mathrm{mm}^{2}\end{array}$ & $\begin{array}{l}\text { Control } \\
\mathrm{mm}^{2}\end{array}$ & $\begin{array}{l}\mathrm{S} / \mathrm{C} \\
\text { ratio }\end{array}$ & $\mathrm{n}$ & $\mathrm{p}$ \\
\hline
\end{tabular}

B. subtilis natto culture solutions

$\begin{array}{llllrl}\text { Naruse strain } & 326.2 \pm 121.5 & 16.4 \pm 20.2 & 19.9 & 38 & * \\ \begin{array}{l}\text { Miyagino strain } \\ \text { Takahashi strain }\end{array} & 486.8 \pm 6.6 & 24.4 \pm 7.2 & 20.2 & 3 & * \\ \begin{array}{l}\text { coli culture solution } \\ \text { E. coli IFO 3301 }\end{array} & 31.3 \pm 5.7 & 17.3 \pm 2.3 & 1.8 & 3\end{array}$

$\mathrm{S} / \mathrm{C}$ ratio $=$ Sample/control ratio. Values denote means $\pm \mathrm{SD}$ unless otherwise stated. The lysis area $\left(\mathrm{mm}^{2}\right)$ on the fibrin plate was measured for $30 \mu \mathrm{l}$ of sample after $48 \mathrm{~h}$ at $37^{\circ} \mathrm{C}$. ${ }^{*} \mathrm{p}<0.001$.
Fig. 5. Effects of heat-treated product of B. subtilis natto culture solution (Naruse strain) on HeLa culture solution. The media collected from cultured HeLa S3 cells were applied on a fibrin plate. Inset Results of a Northern blot analysis of RNA from HeLa S3 cells. The Northern blot analysis used a tPA mRNA hybridization probe and, as a loading control, a GAPDH mRNA hybridization probe.

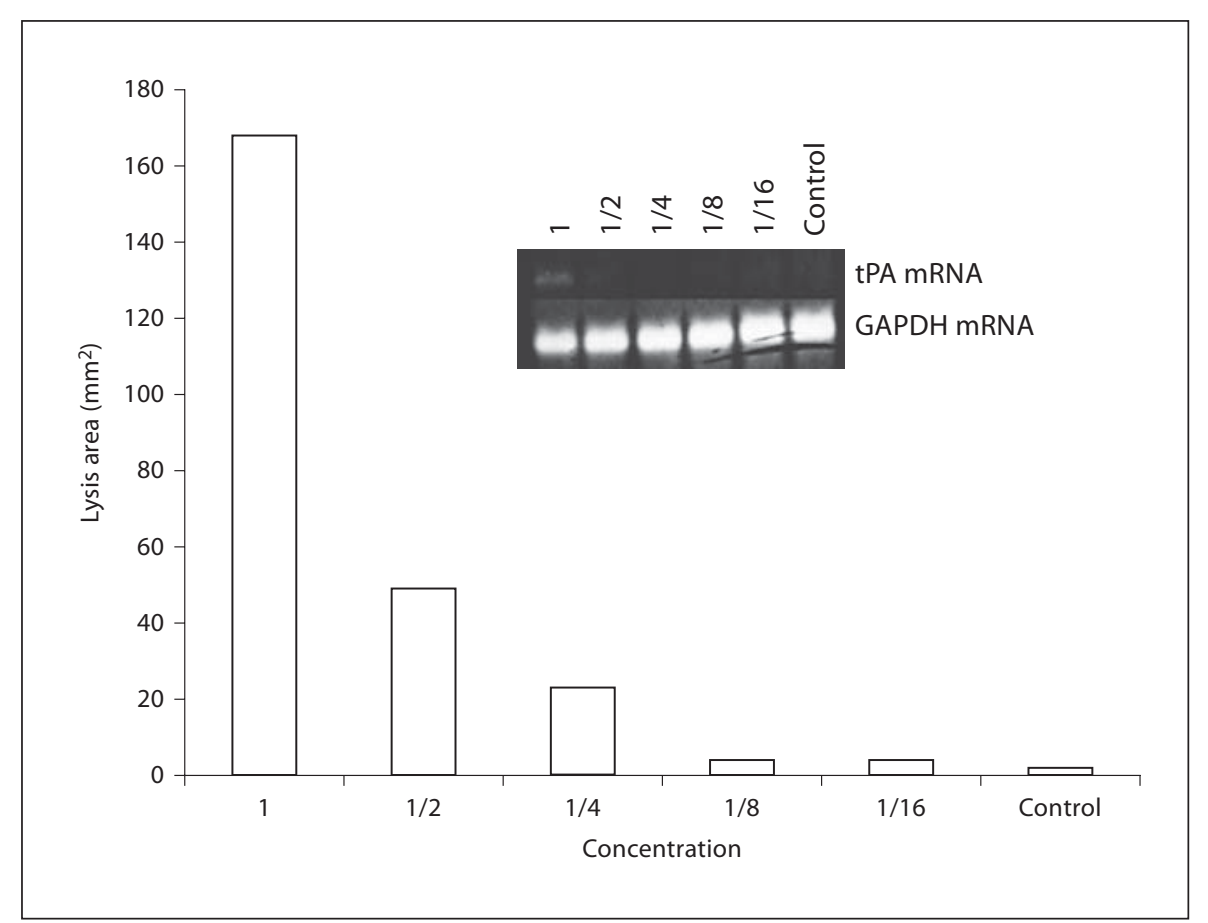

treated product of $B$. subtilis natto culture solution to HeLa cells considerably increased tPA, as shown in the concentrations on a fibrin agar plate. Also, bands were identified in the region, showing the same molecular weight. At the same time, Northern blot analysis results showed increases in the amount of tPA RNA contained in the sample although no change was observed in the amount produced for the internal standard of GAPDH mRNA (fig. 5).

In a comparative test using the heat-treated culture solution of B. subtilis natto, the addition of each sample resulted in an activity that increased the production of tPA from human cells to a level of 10 or more times that of the control $\left(237.3-486.8 \mathrm{~mm}^{2}\right)$. In particular, the cul- 


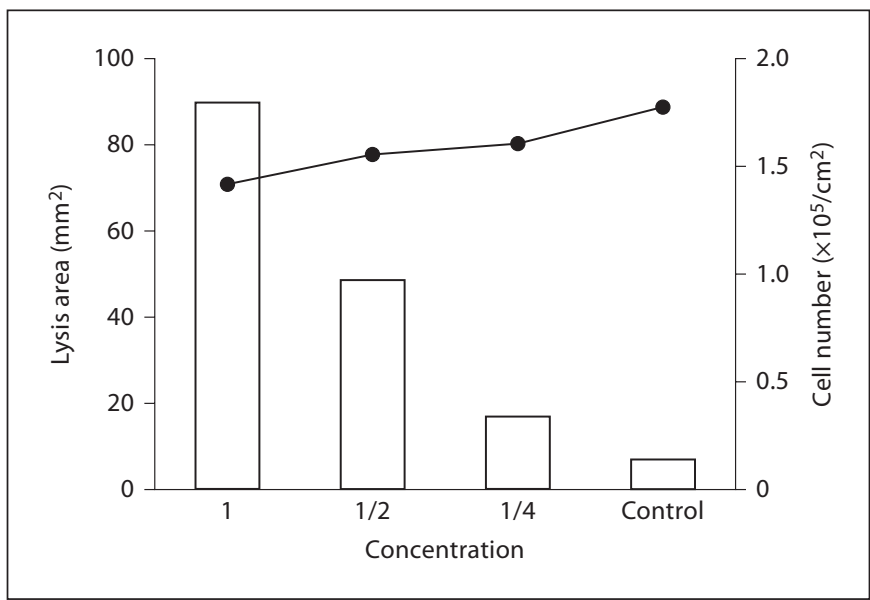

Fig. 6. Effects of heat-treated product of B. subtilis natto culture solution (Naruse strain) on HUVEC culture solution. $\square=$ Fibrinolysis; $\bullet$ cell number.

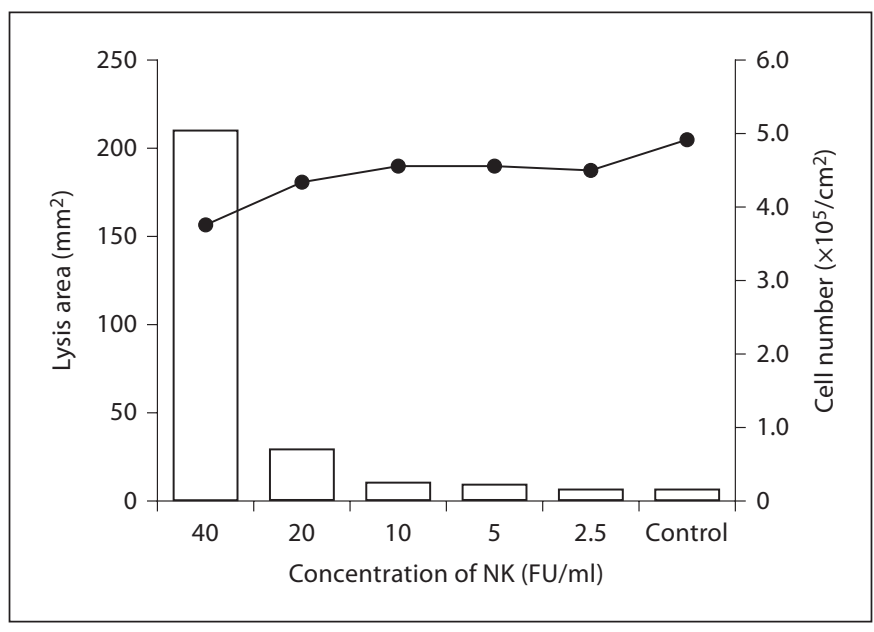

Fig. 7. Effects of heat-treated product of nattokinase (NK) on HeLa culture solution. $\square=$ Fibrinolysis; $\bullet$ = cell number.

ture solution for the Naruse strain displayed a strong activity that was about 20 times as much as the level for the control of water $(326.2 / 16.4 ; \mathrm{p}<0.001 ; \mathrm{n}=38)$. The sample/control ratio was $<2.0$ when the same test was conducted for comparison purposes with the E. coli IFO 3301 strain (table 1).

A check was conducted on the effects of the culture on HUVEC, using the heat-treated product of the culture solution that was obtained by the culture of B. subtilis natto. As shown in figure 6, a strong fibrinolytic activity

Ability of Nattokinase to Generate Tissue Plasminogen Activator compared with the control (water) was observed when the sample was added (89/19 or 4.5 times as much as the control, observed for an undiluted solution, with $\mathrm{n}=5$ ).

Using the heat-treated product of nattokinase, a strong fibrinolytic activity was observed at concentrations of $5 \mathrm{FU} / \mathrm{ml}$ and higher $(0.25 \mathrm{mg})$ in terms of the original enzyme amount (fig. 7). A check of the effects of the addition of nattokinase on HeLa cells, with saline as the control, showed a strong fibrinolytic activity of 24 times that of the control $(215 / 9 ; n=4)$ when the undiluted solution was added. There were no substantial changes in the cell count at the time of the culture for either the HUVEC or the HeLa cells (fig. 6, 7).

\section{Discussion}

Deactivation of the fibrinolytic activity of nattokinase occurred when the nattokinase was heated to $70^{\circ} \mathrm{C}$. It was also found that the synthetic substrates of Suc-Ala-AlaPro-Phe-pNA and H-D-Val-Leu-Lys-pNA were deactivated in addition to fibrinolysis (fig. 1-3). The activity of vascular endothelial and HeLa cells to generate tPA is well known, but it was found in the current study that both of these reaction systems are greatly stimulated by B. subtilis natto culture solution to an enhanced tPA activity (fig. 5; table 1). A Northern blot analysis also confirmed the synthesis of tPA from HeLa cells. The zymography conducted using the culture solution with increased fibrinolytic activity showed that bands could be identified in the same region as that of the tPA standard $(68 \mathrm{kDa})$.

When undiluted solutions were added, an activity of 10 or more times the control was observed for all the nattō samples. This level of activity is noteworthy. Regarding the effects of the Naruse strain on HUVEC and those of nattokinase on HeLa cells, no correlation was found between the amount of the heat-treated product added and the change in cell count (fig. 6, 7). In addition to tPA, a molecular species believed to be the plasminogen activator inhibitor-1/tPA complex was found, but the relationship between urokinase-type plasminogen activator and other proteases is still unclear.

Nattō sold on the market contains $0.6-4.0 \mathrm{mg}$ dipicolinic acid, a substance that is known to be active in antiplatelet aggregation and fibrinolytic systems. This means that someone who eats nattō ingests this amount of dipicolinic acid on a daily basis [13]. Dipicolinic acid is a kind of chelate substance with some notable characteristics such as promoting the growth of $B$. subtilis natto and 
increasing the amounts of nattokinase and vitamin $\mathrm{K}_{2}$ $[14,15]$. Hagiwara et al. [16] reported that sitosterol and fucosterol work on bovine vascular endothelial cells to help release tPA. It was also found that the prostacyclin [17] and prostaglandin $P_{1}[18]$ derivatives show activity in promoting the release of tPA. It has recently been reported that a large amount of tPA is produced in the central nervous system, and tPA is now drawing more attention to its role in neuron movements, neurite outgrowth, neural development, morphogenesis (including spine formation), fluidity, learning, memory, Alzheimer's disease and nerve cell death from anemia [19-21].
Nattokinase products, which capitalize on the strong fibrinolytic activity of the nattokinase enzyme, are currently sold by about 20 companies around the world. However, the possibility has now been raised that even heat-treated nattokinase with no direct fibrinolytic activity may work effectively on cells of living organisms in an indirect manner. Our current plan is to study the active fractions (probably with a molecular weight of 10,000 or less) responsible for these functions to learn what constitutes these fractions and the mechanism at work.

\section{References}

$>1$ Sumi H, Hamada H, Tsushima H, Mihara H, Muraki H: A novel fibrinolytic enzyme (nattokinase) in the vegetable cheese nattō, a typical and popular soybean food in the Japanese diet. Experientia 1987;43:1110-1111.

-2 Sumi H, Hamada H, Nakanishi K, Hiratani $\mathrm{H}$ : Enhancement of fibrinolytic activity in plasma by oral administration of nattokinase. Acta Haematol 1990;84:139-143.

3 Sumi H: Regarding current research trends for the functionality of nattokinase. Food Style 21 2006;10:1-5.

4 Sumi H: The history and functional components of nattō. Jpn J Taste Smell Res 2007; 14: 129-136.

5 Sumi H, Yatagai C: Fermented soybean components and disease prevention; in Sugano M (ed): Soy in Health and Disease Prevention. Boca Raton, Taylor \& Francis, 2005, pp 251-278.

-6 Arts J, Herr I, Lansink M, Angel P, Kooistra T: Cell-type specific DNA protein interactions at the tissue-type plasminogen activator promoter in human endothelial and HeLa cells in vivo and in vitro. Nucleic Acids Res 1997;25:311-317.

7 Waller EK, Schleuning WD: Induction of fibrinolytic activity in HeLa cells by phorbol myristate acetate. J Biol Chem 1985;260: 6354-6360.
$>8$ Astrup T, Müllertz S: The fibrin plate method for estimating fibrinolytic activity. Arch Biochem Biophys 1952;40:346-351.

9 Granelli-Piperno A, Reich E: A study of proteases and protease-inhibitor complexes in biological fluids. J Exp Med 1952;40:346351.

10 Chomczynski P, Sacchi N: Single-step method of RNA isolation by acid guanidinium thiocyanate-phenol-chloroform extraction. Anal Biochem 1987;162:156-159.

11 Medcalf RL, Rüegg M, Schleuning WD: A DNA motif related to the cAMP-responsive element and an exon-located activator protein-2 binding site in the human tissue-type plasminogen activator gene promoter cooperate in basal expression and convey activation by phorbol ester and cAMP. J Biol Chem 1990;265:14618-14626.

12 Fisher RA: Statistical Methods for Research Workers, ed 13. New York, Hafner Publishing, 1958, pp 122-128.

13 Ohsugi T, Ikeda S, Sumi H: Anti-platelet aggregation and anti-blood coagulation activities of dipicolinic acid, a sporal component of Bacillus subtilis natto. Food Sci Technol Res 2005;11:308-310.

14 Ikeda S, Ohsugi T, Sumi H: Activation of fibrinolysis (nattokinase) induced by dipicolinic acid and related compounds. Food Sci Technol Res 2006;12:152-155.

15 Sumi H, Ikeda S, Ohsugi T: Increasing the production of nattokinase and vitamin $\mathrm{K}_{2}$ on nattō with dipicolinic acid. Open Food Sci J 2008;2:151-155.
16 Hagiwara H, Shimonaka M, Morisaki M, Ikekawa N, Inada Y: Sitosterol-stimulative production of plasminogen activator in cultured endothelial cells from bovine carotid artery. Thromb Res 1984;33:363-370.

17 Schneider J: Stimulation of plasma fibrinolytic activity in rats by the prostacyclin analogue CG 4203. Thromb Res 1987;48:233244.

18 Motoyama Y, Sakata Y, Seki J, Sato M, Namikawa Y, Horiai H, Ono T: TFC-612, a prostaglandin $\mathrm{E}_{1}$ derivative, enhances fibrinolytic activity in rats. Thromb Res 1992;65:55-62.

19 Wang YF, Tsirka SE, Strickland S, Stieg PE, Soriano SG, Lipton SA: Tissue plasminogen activator (tPA) increases neuronal damage after focal cerebral ischemia in wild-type and tPA-deficient mice. Nat Med 1998;4: 228-231.

20 Matys T, Pawlak R, Matys E, Pavlides C, McEwen BS, Strickland S: Tissue plasminogen activator promotes the effects of corticotropin-releasing factor on the amygdala and anxiety-like behavior. Proc Natl Acad Sci USA 2004;101:16345-16350.

21 Maeia J, Mikzynska M, Sladek K, Cierniewski CS, Nizankowski R, Szczeklik A: Fibrinolytic activity of prostacyclin and iloprost in patients with peripheral arterial disease. Prostaglandins 1986;31:61-70. 